\title{
Restoration Challenges and Opportunities for Increasing Landscape Connectivity under the New Brazilian Forest Act
}

\author{
Letícia Couto Garcia ${ }^{1 *}$, Juliana Silveira dos Santos², Marcelo Matsumoto1, \\ Thiago Sanna Freire Silva ${ }^{3}$, Aurélio Padovezi ${ }^{1}$, Gerd Sparovek ${ }^{4}$ \& Richard J. Hobbs ${ }^{5}$
}

\author{
${ }^{1}$ Atlantic Forest and Central Savannas Conservation Program, The Nature Conservancy of Brazil, Curitiba, PR, Brazil \\ ${ }^{2}$ Remote Sensing Division, National Institute for Space Research - INPE, São José dos Campos, SP, Brazil \\ ${ }^{3}$ Geography Department, São Paulo State University - UNESP, Rio Claro, SP, Brazil \\ ${ }^{4}$ Department of Soil Science, College of Agriculture "Luiz de Queiroz", University of São Paulo - USP, Piracicaba, SP, Brazil \\ ${ }^{5}$ Ecosystem Restoration \& Intervention Ecology Research Group, School of Plant Biology, \\ University of Western Australia - UWA, Perth, Western Australia, Australia
}

Conservation government policies are main legal mechanisms directly sharping landscape ecology. In Brazil, the two main environmental public policies are the National System of Conservation Units (Sistema Nacional de Unidades de Conservação, SNUC), which regulates the establishment and management of public and sometimes privately owned Protected Areas, and the Brazilian Forest Act (Federal Law 12,651, May 25, 2012 (Brasil 2012), the former Código Florestal, BFA), which regulates the conservation, restoration, and natural vegetation clearing in privately owned lands. As more than $70 \%$ of the Brazilian territory is privately owned (IPEA 2011), the present article discusses the recent substitution of the BFA of 1965 by Law 12,651 of 2012 (heretofore referred to as new BFA: NBFA) and their potential effects on ecosystem conservation, restoration, and landscape integrity. These changes have been justified by agricultural lobbyists stating that compliance with the previous policies would supposedly harm several agricultural business sectors. However, studies have shown this is not necessarily the case (Brancalion \& Rodrigues 2010; Sparovek et al. 2011).

The BFA defines two main mechanisms for the conservation of natural vegetation on privately owned land: Areas of Permanent Preservation (APPs) and Legal Reserves (LRs) (Table S1). There is enough scientific evidence to support these two legal instruments of the BFA (Metzger 2010), and there is increasing scientific concern following the revision of the BFA (Ferreira et al. 2012). Some of the controversial

\footnotetext{
*Send correspondence to: Letícia Garcia

Atlantic Forest and Central Savannas Conservation Program, The Nature Conservancy of Brazil, Rua Padre Anchieta, 392, Mercês, CEP 80410-030, Curitiba, PR, Brazil

E-mail: garcialcbio@yahoo.com.br
}

changes in the BFA are described in detail on Table S2. Compliance with these regulations is the major driver of large-scale ecosystem restoration and conservation on privately owned lands in Brazil, and the recent changes in the BFA both exclude a significant portion of previously protected areas and reduce the extent of mandatory restoration areas. By reducing APP and LR requirements and/or allowing other than restoration of the natural vegetation methods to solve the no-conform areas such as the plantation of forest crops, the NBFA has effectively amnestied mandatory restoration for large areas (Metzger et al. 2010), despite an apparent commitment from different sectors of society to large scale restoration in Brazil.

Initiatives such as the Atlantic Forest Restoration Pact, which aims to restore 15 million ha of Atlantic Forest by 2050 (Calmon et al. 2011) need to be strengthened by the government and civil society to overcome the challenges presented by the implementation of the NBFA (Melo et al. 2013). To demonstrate the negative effects of the NBFA on forest conservation, ecosystem restoration, and landscape integrity, we present two case studies quantifying the changes in APP and LR extent resulting from the new policies. The first case study quantifies the difference in the delimited APP from maximum water bed (i.e., BFA) and from regular watercourse bed (i.e., NBFA - see Table S2), for two Water Resource Management Units (Unidades de Gestão de Recursos Hídricos, UGRHI; Figure S1) in the state of São Paulo, where most of the land has been classified as having high priority for restoration (Joly et al. 2010). The second study case evaluates the reduction in APP, considering the changes in minimum required APP widths, and in RL extent within consolidated agricultural lands, for multiple rural properties distributed across four Brazilian states (Figure S2). 
Both studies examine fragmented landscapes within the Cerrado and Atlantic Forest biomes. Methodological details are included as supplementary material. ${ }^{\star *}$

\section{Case Study 1}

For this study, we evaluated two Water Resource Management Units in the state of São Paulo: one within the Cerrado biome (UGRHI-12), 724 thousand hectares in size, and another within the Atlantic Forest biome (UGRHI-20), 1.32 million ha in size. APPs within each UGRHI were mapped following the remote sensing methods proposed by Rudorff et al. (2012).

NBFA regulations largely reduced the extent of APP required in the evaluated UGRHIs showing a reduction of potential area available for restoration. This reduction was larger for the smaller UGRHI-12, with a 56\% reduction in total APP area, versus $43 \%$ for UGRHI-20 (Figure 1b).

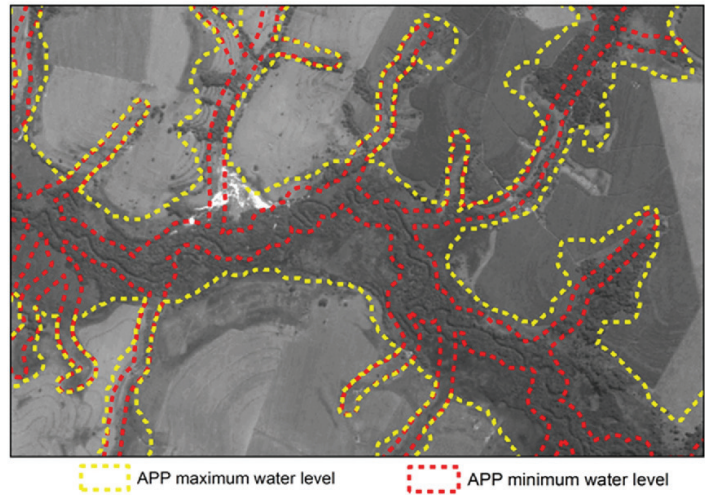

(b)

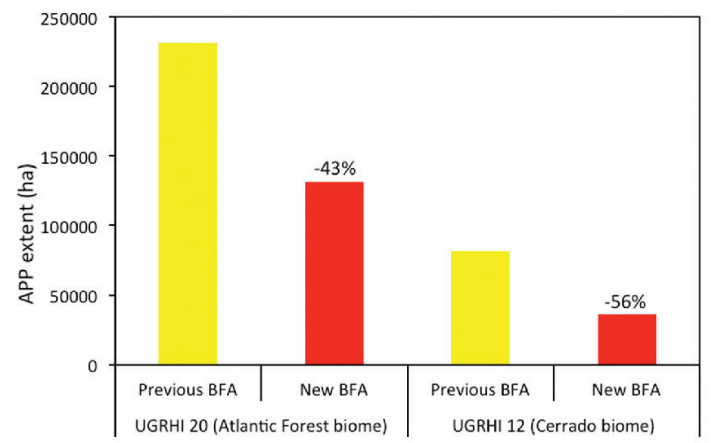

Figure 1. a) APP quantification methodology from the largest (red line: APP maximum water bed level, the limit from which the APP was established in the previous BFA) to the narrowest (yellow line: APP maximum water bed level, the limit from which the APP was established in the previous BFA) seasonal watercourse bed (red line: APP minimum water bed level, the limit from which the APP is established in the NBFA) to the narrowest. b) Reduction in total extent of Areas of Permanent Protection (APPs) resulting from changes in the definition of watercourse limits from the largest to the narrowest seasonal watercourse bed in the NBFA, for two Water Resource Management Units (UGRHIs) in the State of São Paulo.

${ }^{* *}$ see supplementary material available at abeco.org.br.

\section{Case Study 2}

For the second study, we evaluated 57 privately owned properties within the states of Mato Grosso, Brasília, Bahia, and Minas Gerais, $60 \%$ of which are smaller than four fiscal modules (FMs). To determine the actual extent of consolidated agricultural areas within each property, land cover maps were obtained from The Nature Conservancy (TNC) non-governmental organization, and the delineation of APPs was performed according to the NBFA guidelines.

We found a reduction in restoration potential of $54 \%$ and $60 \%$ in APP and LR area, respectively, considering the NBFA regulations for consolidated agricultural areas (Table S4). However, former regulations did not legislate for direct 'active restoration' of APPs, but for 'passive restoration' (e.g., unassisted recovery via natural recolonization after land abandonment) as the former law provided for only isolation of degradation factors (cattle, fire, selective extraction, etc). In this sense, the clear obligation for APP restoration in the NBFA is positive. Potential reduction in restoration area was larger for properties of up to four FMs, as the NBFA exempts these properties from having minimum LR requirements (Figure 2). Moreover, under the NBFA medium and large properties are allowed to include existing APP extent when calculating total LR area for the purpose of meeting minimum requirements, unlike the previous version of the BFA. The combination of these new regulations implies that mandatory conservation/restoration areas are also significantly reduced for properties larger than 10 FMs (54\%) that include consolidated agricultural lands (see detailed results on supplementary material). It is worth noticing that although only $10 \%$ of all rural properties in Brazil are larger than four FMs, they represent about 76\% of the country's area (IPEA 2011).

\section{Discussion and Conclusion}

Overall, results show an average reduction of $50 \%$ in total restoration area owing to changes related to APP limits (i.e., now defined in relation to regular watercourse beds) and 57\%

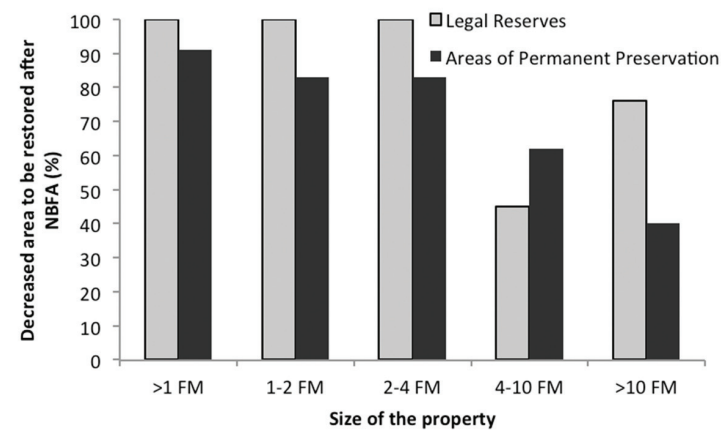

Figure 2. Decreased area (\%) for restoration in Legal Reserves (LRs) and in Areas of Permanent Preservation (APPs) based on standard APP and LR requirements and considering eligible exemptions in the BFA 2012 
owing to minimum restoration area requirements for APP widths and LRs. Hence, the implementation of the NBFA will potentially lead to a reduction in preserved areas and especially in the extent of required restoration areas through BFA enforcement. This reduction was not only tied to specific biomes and physiographic landscape characteristics (relief and size of watercourses), but also to rural property size. Furthermore, considering the particulars of the seasonal flood regimes observed for large Brazilian wetlands, such as the Pantanal, Araguaia, and Amazon regions, as opposed to the Atlantic Forest and Cerrado areas considered in the present study, changes in APP quantification from the largest to the regular seasonal watercourse bed will likely have huge effects on the conservation and restoration of these ecosystems.

Our results show that APP delineation based on the regular watercourse bed will affect mainly regions of flat topography, since areas with more pronounced relief and deeply seated rivers have low seasonal variability in watercourse width. Also, steep slopes (which are also defined as APPs) may be significantly affected by the NBFA changes, as all consolidated rural activities are allowed on slopes between 25 to 45 degrees, hilltops, plateaus, and in areas over 1800 meters for 'small rural properties' (from 20 to 440 hectares depending on the region) and activities such as farming, forestry, and grazing for all properties maintaining crops adapted to high relief conditions. Nevertheless, the highest acceptable slope is $12 \%$ for planting crops like sugarcane, a typical crop that is extensive in the evaluated UGRHIs and in the former Atlantic Forest landscape. This emphasizes the impacts of the NBFA in increasing the potential for agricultural areas to expand significantly in the future.

Under the NBFA, ecosystem restoration will be compromised by the new requirements. Given the changes in watercourse definition, loss of planted vegetation is likely to occur owing to seasonal flooding and edge effects, especially on flat areas, as restoration sites will now be established within the active river floodplains. Considering that plant community composition will be largely determined by the relative size of the fragments in relation to the active river floodplain width (e.g., fragments completely contained within the floodplain will only bear species adapted to temporary flooding conditions, while fragments that encompass upland areas will also house species characteristic of these drier environments) (Metzger et al. 1997), restoration areas based solely on wetland areas will be subject to ecological limitations for flood-intolerant species. As a result, basing the definition of APP extent on the regular watercourse bed will protect mostly riparian vegetation, decreasing or even excluding upland vegetation and leading to losses of functional connectivity between corridors. Riparian buffers are also essential to ensure animal movement along the landscape (Lees \& Peres 2007), and the placement of APPs within the floodplain may prevent organism movement during the wet season because of flooding, reducing the role of protected vegetation as fauna and flora corridors.
Moreover, enhanced edge effects may occur along narrow channels, leading to degradation of riparian vegetation and favoring the colonization by invasive alien species, as well as leading to increased direct sunshine, higher temperatures, and enhanced sediment deposition or erosion, affecting the aquatic fauna (Richardson et al. 2007; Casatti 2010; Tundisi \& Tundisi 2010).

Changes in compensation policies will also negatively affect environmental services and conservation. The NBFA allows compensation of insufficient LR area through the purchase of forested land in regions distant from where native forest amount in the farms is not conform with the requirements established in the NBFA, as long as it is located within the same biome, while the BFA only allowed compensation within the same watershed. Differences in land pricing will result in compensation areas being prioritized according to cost, instead of environmental value, leading to loss of opportunity for maximizing ecosystem services and biodiversity gains at a regional scale (Menz et al. 2013), and triggering landscape degradation. Hence, considering that restoration actions on degraded areas or altered forests can enhance ecosystem functions, biodiversity, and landscape connectivity (Chazdon 2008), compensation established near the place where native forest was removed or degraded would be an opportunity. However, instead of increasing connectivity via compensation areas in fragmented landscapes, this change will continue to compromise future persistence of biodiversity in several areas.

Finally, the new act drastically reduces the extent of restoration in areas of low agricultural potential, mainly in LR areas, which if restored could drastically improve local landscape quality, biodiversity conservation, and environmental services, with negligible losses in productivity. Moreover, it will limit the establishment of new forest patches that could be used by fauna as stepping stones or to maximize the remnant coverage area, reducing edge-effects and improving remnant nuclear areas. The configuration of the landscape after fragmentation, the proximity to forest fragments, and the landscape diversity (heterogeneity) are essential to increase environmental suitability for birds and mammals (Ferraz et al. 2012; Prist et al. 2012). One strong alternative to offset this problem would be the actual enforcement of government incentive packages to encourage restoration of these less productive areas by landowners.

As the directives for forest restoration under the NBFA are based upon property size, enforcement of these regulations will be hindered by the current lack of property boundary data for the Brazilian territory (INCRA 2013; IPEA 2011), and compounded by the lack of accurate topographic, hydrographic, and land cover mapping that already cripples land use planning and management in Brazil (Ribeiro et al. 2010; Sparovek et al. 2011). To overcome this enormous challenge, the Rural Environmental Registry (Cadastro Ambiental Rural, CAR) has been created under the NBFA, as a nationwide electronic public registration system, mandatory for all rural properties, aiming to register farm 
environmental information. The implementation of the CAR is undoubtedly the first and most important challenge to be overcome to enable large scale restoration programs around Brazil. The incentives packages for restoration and conservation of critical areas, prescribed by the NBFA are important opportunities to help connectivity, but most of the landholders were not in compliance with the former $\mathrm{BFA}$, as the government did not enforce full compliance with the law. The main reason is that full compliance is costly, given the requirements for large-scale restoration and the resulting losses in productive area (Sparovek et al. 2012). If compliance with legal APP restoration obligations is enforced, Brazil can have one of the world's largest privately-run riparian restoration programs.

The present study shows two concrete examples of how recent changes in the BFA can severely affect conservation and restoration efforts, and can be worse if the incentives provided by the Program for the Environment Regularization (Programa de Regularização Ambiental, PRA), also included in the NBFA, are not implemented satisfactorily. Hence, government should prioritize public policies that encourage full APP and LR recovery, including mechanisms for payment for providing ecosystem services, production of timber and other forest products (Brancalion et al. 2012).

Brazil houses globally important biomes and biodiversity hotspots, such as the Cerrado, the Atlantic Forest, and the Amazon Rainforest, and has taken a leading role in international negotiations on environmental issues. One of the highlights of the Conference of the Parties on Biological Diversity (COP 10) was Brazil's commitment to restore at least $15 \%$ of degraded ecosystems, ensuring the provision of environmental services and contributing to mitigation and adaptation to climate change. The NBFA certainly brings challenges to achieve this goal, especially if the incentive measures for restoration and conservation also provided in NBFA are not quickly implemented. Furthermore, economic incentive policies such as payment for environmental services to landowners to restore and conserve priority areas will be fundamental to safeguard natural Brazilian ecosystems.

\section{Acknowledgements}

We thank J.P. Metzger, R.R. Rodrigues, S. Gandolfi, C.R. Fonseca, J. Louzada, and R. Pardini who provided valuable suggestions that improved previous versions of the Table S1, S2. We are grateful to P.H.S. Brancalion and two anonymous reviewers for their insights comments that greatly improved the manuscript.

\section{References}

Brancalion PHS \& Rodrigues RR, 2010. Implicações do cumprimento do Código Florestal vigente na redução de áreas agrícolas: um estudo de caso da produção canavieira no Estado de São Paulo. Biota Neotropica, 10:63-66. http:// dx.doi.org/10.1590/S1676-06032010000400009
Brancalion PHS et al., 2012. Finding the money for tropical forest restoration. Unasylva, 63:25-34.

Brasil, 2012. Lei $n^{\circ} 12.651$, de maio de 2012. Available from: $<$ http://www.planalto.gov.br/ccivil_03/_Ato2011-2014/2012/ Lei/L12651.htm>.

Calmon M et al., 2011. Emerging Threats and Opportunities for Large-Scale Ecological Restoration in the Atlantic Forest of Brazil. Restoration Ecology, 19:154-158. http://dx.doi. org/10.1111/j.1526-100X.2011.00772.x

Casatti L, 2010. Alterações no código florestal brasileiro: impactos potenciais sobre a ictiofauna. Biota Neotropica, 10:31-34. http://dx.doi.org/10.1590/S1676-06032010000400002

Chazdon RL, 2008. Beyond deforestation: restoring forests and ecosystem services on degraded lands. Science, 320:14581460. http://dx.doi.org/10.1126/science.1155365

Ferraz KMPM et al., 2012 Environmental suitability of a highly fragmented and heterogeneous landscape for forest bird species in south-eastern Brazil. Environmental Conservation, 39:316-324. http://dx.doi.org/10.1017/S0376892912000094

Ferreira J et al., 2012 Towards environmentally sustainable agriculture in Brazil: challenges and opportunities for applied ecological research. Journal of Applied Ecoloy, 49:535-541.

Instituto de Pesquisa Econômica Aplicada - IPEA, 2011. Código Florestal: implicações do PL 1876/99 nas áreas de reserva legal. IPEA. p. 1-23. Available from: <http://www.socioambiental. org/banco_imagens/pdfs/Cod_Florestal_Ipea_Jun_2011. pdf $>$.

Instituto Nacional de Colonização e Reforma Agrária - INCRA, 2013. Certificação de imóveis rurais. Available from: <http:// www.incra.gov.br/>.

Joly CA et al., 2010. Biodiversity Conservation Research, Training, and Policy in São Paulo. Science, 328:1358-1359. http://dx.doi.org/10.1126/science.1188639

Lees AC \& Peres CA 2007. Conservation value of remnant riparian forest corridors of varying quality for Amazonian birds and mammals. Conservation Biology, 22:439-449. http://dx.doi.org/10.1111/j.1523-1739.2007.00870.x

Melo et al., 2013. Priority setting for scaling-up tropical forest restoration projects: Early lessons from the Atlantic Forest Restoration Pact. Environmental Science \& Policy. In press. http://dx.doi.org/10.1016/j.envsci.2013.07.013

Menz MH, Dixon KW \& Hobbs RJ, 2013. Hurdles and opportunities for landscape-scale restoration. Science, 339:526-527. http://dx.doi.org/10.1126/science.1228334

Metzger JP, Bernacci LC \& Goldenberg R 1997. Pattern of tree species diversity in riparian forest fragments of different widths (SE Brazil). Plant Ecology, 133:135-152. http://dx.doi. org/10.1023/A:1009791831294

Metzger JP, 2010. O código florestal tem base científica? Natureza \& Conservação, 8:92-99. http://dx.doi.org/10.4322/ natcon.00801017

Metzger JP et al., 2010. Brazilian law: full speed in reverse? Science, 329:276. http://dx.doi.org/10.1126/science.329.5989.276-b

Prist PR, Michalski F \& Metzger JP, 2012. How deforestation pattern in the Amazon influences vertebrate richness and 
community composition. Landscape Ecology, 27:799-812. http://dx.doi.org/10.1007/s10980-012-9729-0

Ribeiro CAAS et al., 2010. Áreas de preservação permanente: espaços (im)possíveis. Ambiência, 6:93-102.

Richardson DM et al., 2007. Riparian vegetation: degradation, alien plant invasions, and restoration prospects. Diversity and Distributions, 13:126-139. http://dx.doi. org/10.1111/j.1366-9516.2006.00314.x

Rudorff BFT et al., 2012. Identificação de áreas de preservação permanente ciliares a partir das feições da paisagem $e$ imagens de sensoriamento remoto em regiões produtoras de cana-de-açúcar no Estado de São Paulo. São José dos Campos: INPE. 66 p.
Sparovek G et al., 2011. A revisão do código florestal brasileiro. Novos Estudos, 89:111-135. http://dx.doi.org/10.1590/ S0101-33002011000100007

Sparovek G et al., 2012. The revision of the Brazilian Forest Act: increased deforestation or a historic step towards balancing agricultural development and nature conservation? Environmental Science \& Policy, 16:65-72. http://dx.doi. org/10.1016/j.envsci.2011.10.008

Tundisi JG \& Tundisi TM, 2010. Impactos potenciais das alterações do Código Florestal nos recursos hídricos. Biota Neotropica, 10:67-75. http://dx.doi.org/10.1590/ S1676-06032010000400010

Received: March 2013

First Decision: July 2013

Accepted: October 2013 